\title{
Organic Bed Biofiltration: A new Technology for Simultaneously Deodorization of Liquid and Gaseous Effluents on Pig Farms
}

\author{
G. Buelna, N. Turgeon and R. Dubé \\ Centre de Recherche Industrielle du Québec (CRIQ) \\ E-mail: gerardo.buelna@criq.qc.ca
}

(Recibido: marzo de 2006: aceptado: septiembre de 2006)

\section{Resumen}

El rápido crecimiento de la indu stria porcina ha originado serios problemas ambientales asociados a los olores ofensivos, generados en las insatalaciones de produccion y durante el almacenamiento, el transporte y la descarga de las aguas residuales porcinas. Entre las alternativas de tratamiento existentes, la biofiltración en lecho orgánico representa una tecnología de alto potencial para la desodorización y el tratamiento de los efluentes líquidos y gaseosos producidos en las granjas porcinas. Trabajos de investigación y desarrollo tecnológico fueron realizados durante seis años en una granja porcina situada en Quebec, Canadá, con el objetivo de adaptar y optimizar el funcionamiento del proceso de biofiltración BIOSORMC - Estiercol al tratamiento simultáneo de efluentes líquidos y gaseosos generados por esta agroindustria. Estos trabajos se efectuaron a una escala industrial utilizando un sistema de biofiltración de $560 \mathrm{~m}^{3}$. Los resultados obtenidos muestran que el proceso BIOSORMC - Estiercol es una tecnología robusta, simple y eficiente que ofrece una solución global al problema de gestión de los olores ofensivos. Efectivamente, esta tecnología reduce más del 95\% de la carga contaminante (NH3, H2S) y más del $80 \%$ de la intensidad de los olores generados por la granja porcina.

Descriptores: Estiércol de puerco, olores ofensivos, efluentes líquidos y gaseosos, análisis olfactométricos, desodorización, tratamiento, biofiltración.

\footnotetext{
Abstract

The growth of pig in dus try has caused a great prob lem of un de sir able odours, par tic ularly in and around pro duc tion build ings, stor age ar eas and when the pig ma nure is spread. Among ma nure treat ment op tions, or ganic bed biofiltration rep re sents a very prom is ing tech nique for the deodorization and treat ment of pig ma nure. Re search and de vel op ment work to op ti mize the BIOSORTM-Manure, a biofiltration pro cess for si mul taneously treat ment of liq uid and gas eous effluents on pig farms, have been real ized on the site of a pig gery (Île d'Orléans, Québec,Can ada) us ing a $560 \mathrm{~m} 3$ biofiltration system. The re sults ob tained show that the BIOSORTM-Manure pro cess is an efficient, sim ple and per form ing tech nol ogy bring ing a global so lu tion to odours pig ma nure prob lems. Actually, the pro cess re duce over $95 \%$ the pol lut ing load from the gas of the pigfarm (NH3, H2S), the BIOSORTM-Manure pro cess elim i nates over $80 \%$ the odour in ten sity com ing from the production in stalla tions, the storage, the trans por ta tion and
} 
Organic Bed Biofiltration: A new Technology for Simultaneously Deodorization of Liquid ...

the spread ing of the ma nure.

Keywords: Pig ma nure, odours, liq uid and gas eous effluents, olfactometrical anal y sis, deodorization, treat ment, biofiltration.

\section{Introduction}

The agricultural sector is grappling with a growing problem associated with the odour pollution that it generates. One of the most affected sectors is the porcine production industry, which currently represents the most blatant nonpoint source pollution management problem. Pig production has grown considerably in Quebec, with the number of pigs almost tripling in the last 25 years. This development has led to a surplus of pig manure to be discharged in relation to the available spreading area and consequently, a water, air and soil pollution problem, along with undesirable odours primarily generated by the production building and the storing and spreading of pig manure. Considering the intensity and duration of the odours, the proposed weighting of odour sources for Quebec is 20\% for the building, $10 \%$ for the storage, $5 \%$ for the collection and $65 \%$ for the spreading ( $\mathrm{O}^{\prime} \mathrm{Neill}$ and Stewart, 1985; Héduit, 1989; Buelna et al., 1993).

The main source of odour in terms of pig installations comes from the manure and their management. Even though there are over 150 volatile combinations in pig manure (Merkel et al., 1969; Schaeffer et al., 1977; Yasuhara et al., 1983), the main components are methane, carbon dioxide, ammonia and hydrogen sulphide (Lee, 1976; McQuitty et al., 1983; Lasbleiz,1989).

According to their detection limit and their olfactory character, ammonia and hydrogen sulphide have been identified as being good indicators to monitor odours emanating from the treatment of pig manure (Pain et al., 1990, Martin and Laffort, 1991).

Increasingly stringent environmental standards, constantly growing public awareness of environmental problems and the conflicts associated with living with unpleasant odours, have led to enhanced research into various alternatives for treating pig manure in different countries. One alternative, the organic bed biofiltration is a very promising technology for the deodorization and treatment of liquid and gas effluents in reducing the overall odour problem at the farm (building, storage, spreading).

The biofiltration by organic media is a simultaneous AIRNATER treatment process (Buelna et al ., 1997) for the global management of porcine production effluents. The principle consists of passing the liquid (manure) and gas (foul air) effluents through an organic media biofilter (mixture of peat moss, woodchips, etc.). As a pollutant removal agent, the organic media can act in two ways, as a natural resinable to fix several types of pollutants and/or as support for various types of micro-organisms capable of degrading the retained substances. These pollutants are degraded into $\mathrm{CO}_{2}$ and $\mathrm{H}_{2} \mathrm{O}$ due to the microbial activity (Bélanger et al., 1987). The constituents of the organic media, particularly the lignin and organic acids, possess numerous polar functional groups: alcohols, phenols, aldehydes, cetones, acids, ether. This polar characteristic gives it a good adsorption capacity for organic molecules and transition metals (Coupal and Lalancette, 1976). Adsorption properties can also be linked to the presence of a porous structure, conducive to physical adsorption (Tinh et al., 1971).

Given the potential of this technology, large scale research and development work has been conducted on a 150 sows farrow-to-finish operation on Île d'Orléans (Québec, Canada) using an industrial biofiltration system of 560 cubic metres total volume (primary biofilter: 400 cubic metres, polishing biofilter: 160 cubic 
metres). This work aimed to demonstrate the overall efficiency of the BIOSOR ${ }^{\mathrm{TM}}$ system to reduce odours in terms of manure produced and foul air coming from the livestock buildings.

Ammonia $\left(\mathrm{NH}_{3}\right)$, hydrogen sulphide $\left(\mathrm{H}_{2} \mathrm{~S}\right)$ and odour intensity (olfactometry) were subject to rigorous monitoring to establish the deodorization performance of the biofiltration system.

The system installed on the farm offers a purifying efficiency of over $95 \%$ for $\mathrm{NH}_{3}$. The measured elimination performances exceed $99 \%$ for $\mathrm{H}_{2} \mathrm{~S}$. System efficiency is maintained at around $80 \%-85 \%$ for odour intensity reduction. Moreover, foul air and raw manure from the livestock buildings, considered to be annoying, indeed unacceptable, are deodorized to reach an acceptable level after they pass through the biofilter (Buelna et al, 1998).

The results obtained during the long-term monitoring of the technology's purifying performance (6 years), show that the technology developed by the CRIQ is a simple and efficient treatment system adapted to the needs of agricultural enterprises, which is a substantial asset for the evolution of the sustainable development of this industry.

\section{Mate rials and Methods}

An industrial biofiltration system was designed, built and implemented in January 1997, to treat the liquid and gas effluents of a 150 sows farrow-to-finish operation (about 3,000 pigs produced per year). The system was designed to simultaneously treat up to 12 cubic metres/d of manure and 15,000 cubic metres $h$ of foul air. Figure 1 shows that the pig manure is treated by first separating the liquid and solid parts in a sedimentation tank and a 1,200 cubic metres digester (existing storage tank reused for the needs of the system). The system stabilizes and deodorizes the sludge ( $20 \%$ of the total volume of the manure) through anaerobic digestion. The residual liquid fraction $(80 \%)$ is directed to a protection prefilter. This fraction is then pumped to the surface of a 400 cubic metres primary biofilter composed of a multi-layer organic bed non inoculated (70\% woodchips, 30\% peat moss). In order to reach a degree of purification to consider discharge to the environment, the waters are finally directed into a 160 cubic metres polishing biofilter (non inoculated, 70\% woodchips, $30 \%$ peat moss). The treated water is stored in an existing tank (2,600 cubic metres) before being used to wash the gutters or for irrigation. The foul air from the production building is directed to the base of the two biofilters to perform a countercurrent treatment.

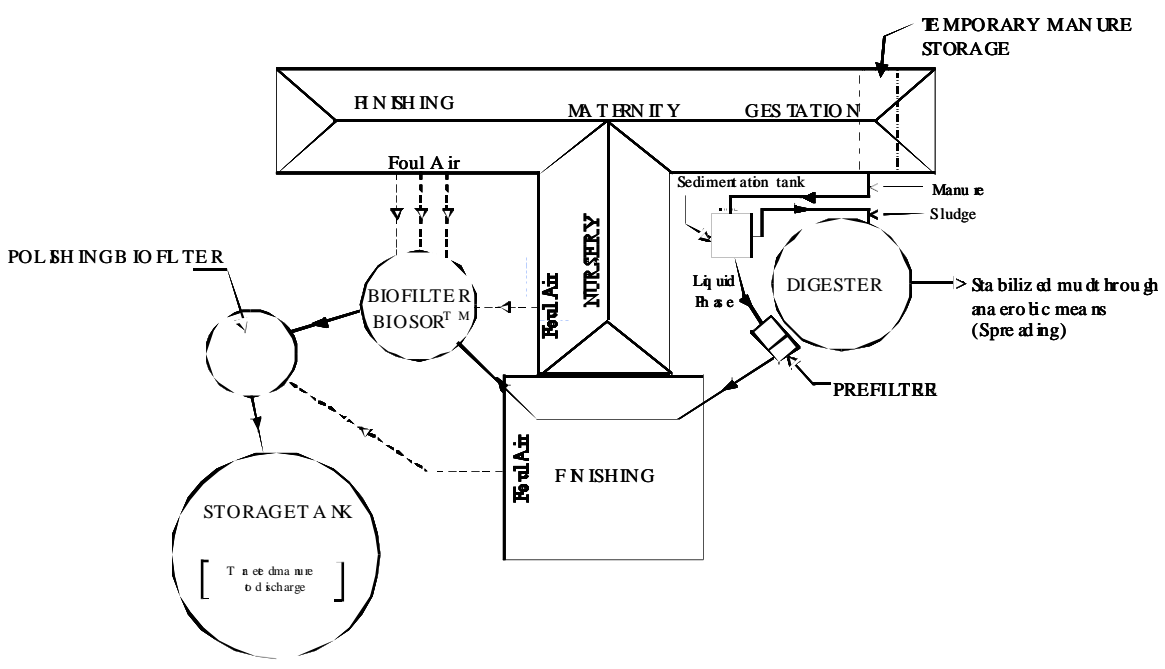

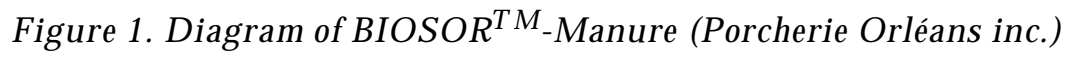




\section{Measuring Purification Efficiency}

We have used two complementary approaches to determine the deodorization performance of the biofiltration system. The first is the classic physiochemical analysis to evaluate the concentration of ammonia $\mathrm{NH}_{3}$ and hydrogen sulphide $\mathrm{H}_{2} \mathrm{~S}$, the two main compounds responsable for the odours. The second is olfactometry, a sensory analysis method that calls upon a jury to quantify the perceived odours.

\section{Analytical Approach}

The sampling method selected to characterize the foul air from the buildings housing the pigs is a selective sampling device by family of components (Le Cloirec et al., 1991). This technique consists of trapping the volatile components to be dosed with specific reactives. The ammonia trapped in the form of ammonium ions in the hydrochloric acid solution is dosed by colorimetry using the Nessler reactive according to the AFNOR NFT 90.15 norm. The sulphated components are quantified by iodometric dosage according to the SMEWW-4500 $S^{2}-F$ Iodometric Method (APHA, 1995). N-NTK was analyzed in accordance with Standard Methods (1995).

\section{Sensory Approach}

To perform the sensory analysis of the gas effluents, it was used the TECNODOR ${ }^{\mathrm{TM}}$, dynamic dilution olfactometer based on the principal of the suprathreshold measure (ASTM E544 American standard, VDI 3882 German standard and AFNOR X43-103 French stan- dard). The TECNODOR ${ }^{\mathrm{TM}}$ is a mobile machine that allows in situ measurement. The principle consists of having a jury of at least four people smell the odour to be evaluated. The intensity of the perceived odour is then compared with the intensity provided by a specific concentration of a reference substance (1-butanol) generated by the olfactometer. The intensity of the ambient odour is then expressed as an equivalent ppb of 1-butanol. For the comparative olfactometrical analysis of the liquid (raw and treated manure), we used a dynamic flux chamber (Eklund, 1992; Gholson et al., 1991) that channels the fumes and prevents their dispersion in the ambient air when the olfactometric measure is taken.

In addition to measuring the intensity of the perceived odours, we have also evaluated the hedonic character of the perceived odours, i.e. the degree of acceptability experienced by each jury member upon exposure. To do this, we used the method suggested by Martin and Laffort (1991) which consists of determining the Odour Nuisance Index (ONI).

\section{Results and Discussion}

\section{Performance of the Elimination of Ammonia and Hydrogen Sulphide}

Table 1 shows the results obtained for the determination of ammonia concentrations $\left(\mathrm{NH}_{3}\right)$ and hydrogen sulphide $\left(\mathrm{H}_{2} \mathrm{~S}\right)$ present in the foul air of the livestock buildings and when it comes out of the biofilters (averages for six years).

Table 1. Elimi na tion of Target Compounds $\left(\mathrm{NH}_{3}\right.$ and $\left.\mathrm{H}_{2} \mathrm{~S}\right)$

\begin{tabular}{ccccc}
\hline \multirow{2}{*}{ Period } & Compounds & \multicolumn{2}{c}{ Average Concentration (ppmv) } & $\begin{array}{c}\text { Elimination } \\
\text { Performances (\%) }\end{array}$ \\
\cline { 3 - 4 } & $\mathrm{NH}_{3}$ & Biofilter entry & Biofilter exit & $>95$ \\
\multirow{2}{*}{ Summer } & $\mathrm{H}_{2} \mathrm{~S}$ & 0.35 & 0.11 & $>99$ \\
& $\mathrm{NH}_{3}$ & 6.034 & undetected & $>98$ \\
\multirow{2}{*}{ Fall } & $\mathrm{H}_{2} \mathrm{~S}$ & 0.186 & 0.07 & $>99$ \\
\hline
\end{tabular}


The increased concentrations in biofilter entries observed in the fall are caused by a decrease in the farm's ventilation rates. This operation is performed in order to comply with minimum ventilation rate criteria for the winter. This rate is completely taken up by the biofilter supply fans.

Ammonia is the compound with the highest concentrations varying between 2.3 and 6.7 ppmv. Even though they appear weak, the hydrogen sulphide concentrations measured in the foul air (0.03 to $0.19 \mathrm{ppmv}$ ) are nevertheless higher than the perception threshold for this compound (Le Cloirec et al., 1991).

The system maintained purifying efficiencies greater than $95 \%$ for $\mathrm{NH}_{3}$ during six years of operation. The measured elimination performances exceed $99 \%$ for $\mathrm{H}_{2} \mathrm{~S}$.

\section{Odour Reduc tion (Foul Air in the Live- stock Buildings)}

The results of the sensory measures show a net difference between the foul air and the treated air. This difference essentially resides in the intensity of the perceived odour and the level of discomfort felt by the jury. Table 2 reveals that the farm's ambient air is characterized by a strong intensity qualified as annoying, even unacceptable. The air that comes out of the biofilter provides a slight olfactory sensation that is deemed acceptable. Moreover, the air treated by biofiltration has an odour described as being like a wetland (characteristic odour of peat moss). The biofilter therefore has a dual role: it breaks down the pollutants from the farm $\left(\mathrm{NH}_{3}\right.$ and $\left.\mathrm{H}_{2} \mathrm{~S}\right)$ and it gives the gas stream an acceptable odour. System efficiency is main- tained at around $80 \%-85 \%$ for the reduction in odour intensity. This reduction was not affected by winter time and summer time temperatures $\left(-25^{\circ} \mathrm{C} ;+25^{\circ} \mathrm{C}\right)$ and the load applied to the biofilter.

\section{Olfactometric Measures on the Liquid Fraction (Treated and Untreated Manure)}

The results of the sensory measures also show a net difference between the raw manure and the treated manure. Figure 2 reveals that the biofiltration system reduced the odour intensity by over $4,000 \mathrm{ppb}$ of 1-butanol to about $600 \mathrm{ppb}$ of 1-butanol. In addition, the raw manure qualified as unacceptable is deodorized to reach an acceptable level after passing through the biofilter. The odour of the treated water that comes out of the biofilter also has a wetland smell (peat moss).

\section{Distribution of the Primary Nitrogenous Forms}

Loads high in N - NTK were treated by the biofiltration system (see figure 3 ). In spite of a total entry load of $61.4 \mathrm{~g} \mathrm{~N} / \mathrm{m}^{2}-\mathrm{d}$, the average load of liquid effluent treated was maintained at about $10 \mathrm{~g} \mathrm{~N} / \mathrm{m}^{2}$-d and that of the gas effluent did not exceed $0.1 \mathrm{~g} \mathrm{~N} / \mathrm{m}^{2}-\mathrm{d}$, for an overall purifying efficiency of $84 \%$. Even though several mechanisms are involved in the conversion of nitrogen during the biofiltration by supported organic media (filtration, sorption, biotransformation, volatilization), a mass balance carried out by Garzón-Zúñiga (2001) revealed that simultaneous nitrification-denitrification (SND) is the most important means of transformation within the $\mathrm{BIOSOR}^{\mathrm{TM}}-\mathrm{Ma}$ -

Table 2. Char ac ter is tics of Odours Measured upon Entering and Exiting the Biofilter

\begin{tabular}{|c|c|c|c|c|c|c|}
\hline \multirow[t]{2}{*}{ Period } & \multicolumn{2}{|c|}{$\begin{array}{l}\text { Average Odour } \\
\text { Intensity } \\
\text { (ppb 1-butanol) }\end{array}$} & \multirow[t]{2}{*}{ Reduction } & \multirow[t]{2}{*}{ Period } & \multicolumn{2}{|c|}{ Odour Nuisance Index (ONI } \\
\hline & Biofilter entry & Biofilter exit & & & Biofilter entry & Biofilter exit \\
\hline Summer & 5,270 & 850 & $84 \%$ & Summer & Annoying & Acceptable \\
\hline Fall & 12,170 & 2,200 & $82 \%$ & Fall & Unacceptable & Acceptable \\
\hline
\end{tabular}


Organic Bed Biofiltration: A new Technology for Simultaneously Deodorization of Liquid ...

nure process. In fact, the establishment of a detailed mass balance realized over a 180-day period revealed that $30 \%$ of the N - NTK is transformed into molecular nitrogen $\mathrm{N}_{2}$ and $10 \%$ of the N - NTK is found in the form of N -
$\mathrm{NO}_{3}$. The micro-organisms involved in the biotransformation assimilated about $16 \%$ of the $\mathrm{N}$ - NTK for their growth and $6 \%$ of the N - NTK was accumulated in the filter bed.

\section{Intensité}

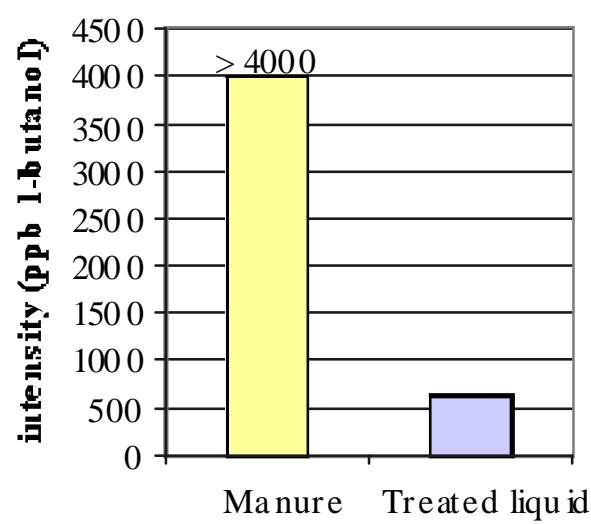

INO

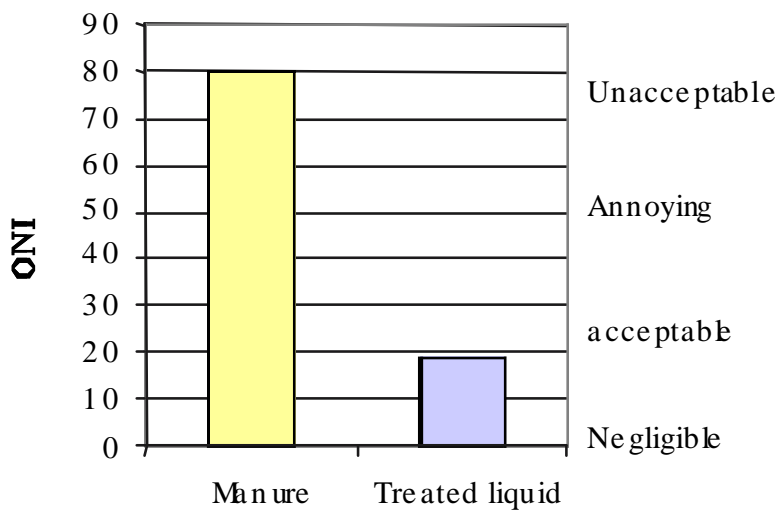

Figure 2. Sensory Measures Carried Out on the Liquid Frac tion (Raw Manure and Treated Liquid)

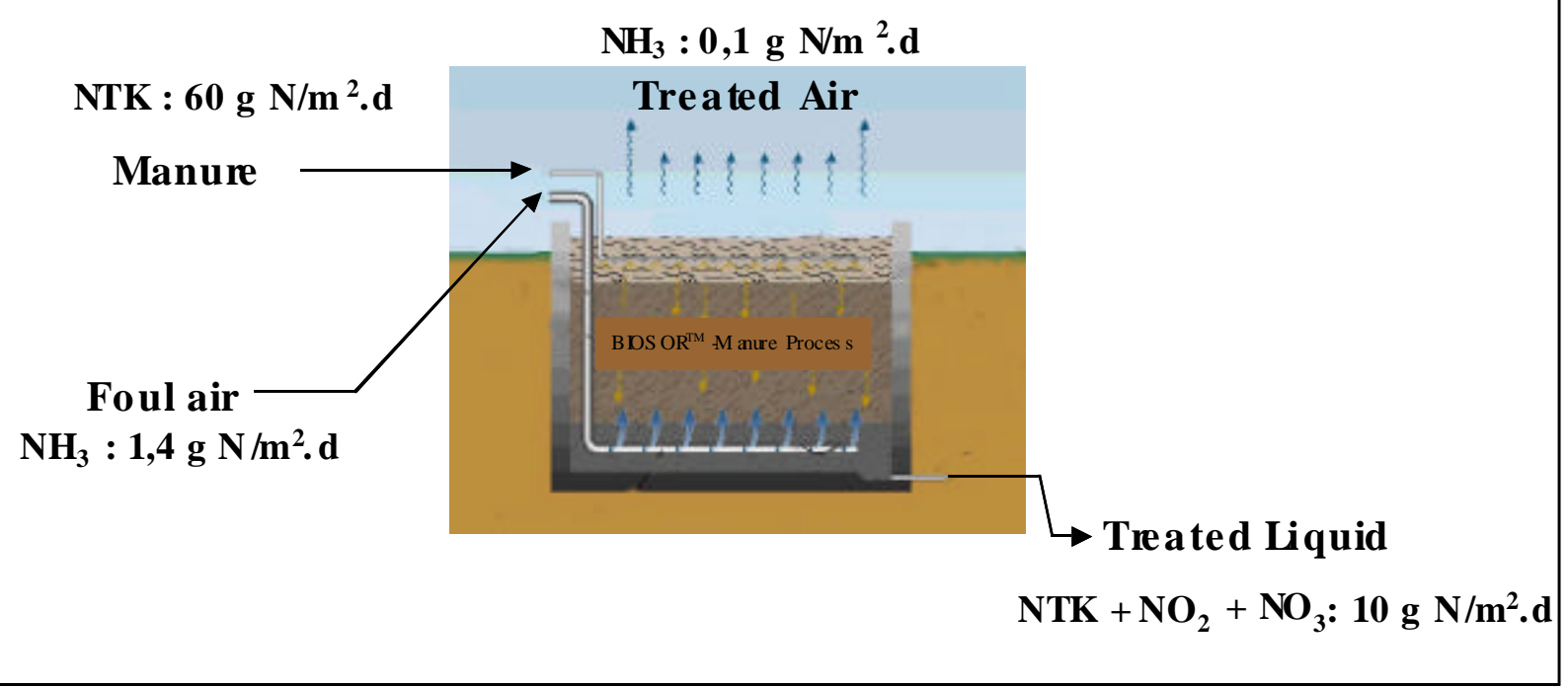

Figure 3. Distribu tion of the Primary Nitrog e nous Forms 


\section{Conclusions}

The results obtained during this project reveal that the BIOSOR ${ }^{\mathrm{TM}}$-Manure biofiltration process represents a solution to the overall problem of porcine farm odour. Its dual role enables the biofilter to break down pollutants from the farm and provide treated foul air and manure with an acceptable odour (peat moss).

The passage of gas effluents in biofilters reduces $(>95 \%)$ the concentration of target compounds $\left(\mathrm{NH}_{3}\right.$ and $\left.\mathrm{H}_{2} \mathrm{~S}\right)$ present in the foul air of livestock buildings. Moreover, sen- sory measures show that the biofilter reduces the intensity $(>80 \%)$ of odours generated by livestock production activities and the management of manure (buildings, storage, transportation and spreading).

The sensory analysis method used (TECNODOR ${ }^{\mathrm{TM}}$ olfactometer) resulted in an in situ evaluation of the sensation actually perceived (intensity) by integrating the hedonic aspect (pleasant or unpleasant character) of the odour.

Moreover, the biofiltration process has turned out to be a technological alternative enabling simple and efficient management of highly charged nitrogenous effluents. The long-term follow up study (6 years) shows that the technology performed well in spite of major variations in temperature and pollutant loads.

In light of these results, there is no doubt that the biofiltration process developed by the CRIQ represents a rugged, simple and efficient technology to solve the overall environmental problem associated with unpleasant odours generated by the management of pig manure. The biofiltration system is installed directly on the producer's pig farm with no impact on production control while recuperating existing storage reservoirs. This technology now makes it possible to reconcile people's environmental concerns with the pork industry's potential for growth.

\section{References}

AFNOR (1975). Essais des Eaux. Dosage de l'azote Ammoniacal. Norme NFT 90.15, Paris.

AFNOR (1995). Qualité de l'air. Mesures Olfactométriques- Mesurage de l'odeur d'un Effluent Gazeux. Méthodes Supraliminaires. Norme X43-103. AFNOR, Tour Europe Cedex 7, 92080 Paris La Défense, France.

APHA (1995). Amer ican Public Health Asso ciation. American Water Works Association and Water EnvironmentFederation. Standard Methods for Examination of Water and Wastewater, 19 th Ed., Washington, D.C.

ASTM E544 (Reapproved 1988). Standard Prac tices for Refer encing Suprathreshold Odor Inten sity. Philadelphia: American Society for Testing and Mate rials.

Bélanger A., Potvin D., Cloutier R. et Caron M. (1987). La Tourbe: une Ressource d'avenir. Étude Réalisée pour le Centre Québécois de Valo ri sa tion de la Biomasse, $125 \mathrm{pp}$.

Buelna G., Caouette P. et Pigeon S. (1993). Désodorisation des Lisiers: Étude Comparative des Principales Technologies Existantes à l'aide des Bilans et Selon une Approche Intégrée. Sciences et Techniques de l'eau, Vol. 26, No. 4, novembre.

Buelna G., Dubé R., Michel M.C., Turgeon N., Bernard Y. et Lessard P. (1997). Traitement Global du Lisier de Porc par le Procédé de Biofiltration BIOSOR ${ }^{\mathrm{MC}}$ Lisier. 20e Symposium AQTE/AESEQ, Montréal, 19-20 novembre.

Buelna G., Dubé R., Michel M.C., Turgeon N., Bernard Y. and Lessard P. (1998). Comprehensive Pig Manure Treatment Using the B1OSOR ${ }^{T M}$ Biofiltration Process. In: Ramiran $98.8^{\text {th }}$ International Conference on Management Strategies for Organic Waste use in Agriculture. Cemagref - FAO (ed.), France.

Coupal B., Lalancette J.M. (1976). The Treatment of Wastewaters with Peat Moss. Water Research, Vol. 10, pp 1071-1076. 
Organic Bed Biofiltration: A new Technology for Simultaneously Deodorization of Liquid ...

Eklund B. (1992). Practical Guidance for Flux Chamber Measure ments of Fugi tive Volatile Organic Emission Rates. ISSN 1047-3289. J. Air Waste Manage. Assoc. 42, pp.1583-1591.

Garzón-Zúñiga M. (2001). Mécanismes d'enlèvement de l'azote du Lisier de Porc par Biofiltration aérée sur Tourbe. Thèse de Doctorat, Département de Génie Civil, Université Laval, Québec, Canada. 194 p A-72 p.

Gholson A.R., Albritton J.R., Jayanty R.M. K., Knoll J.E. and Midgett M.R. (1991). Évaluation of an Enclosure Method for Measuring Emis sions of Vola tile Organic Compounds from Quiescent Liquid Surfaces. Enviro. Sci. Technol. 25, pp. 519524.

Héduit M. (1989). Pays-Bas: l'environnement en Marche. Techni-Porc 12(2): 21-31.

Lasbleiz M. (1989). Étude des Procédés Physico-chimiques d'épuration du Lisier de Porc. Université de Rennes I, thèse no d'ordre 366, France.

Le Cloirec P., Fanlo J.L., Degorce-Dumas J.R. (1991). Traitement des Odeurs et Désodorisation Industriell e. Inno va tion 128 Éd. Paris.

Lee R.E. (1976). Air Pollution from Pesticides and Agricultural Processes. CRC Press inc., Ohio, USA.

Martin G., Laffort P. (1991). Odeurs et Désodorisation dans l'environnement. TEC et DOC-Lavoisier, Paris, p. 452.

McQuitty J.B., Maclean A.J. (1983). L'effet du Fumier dans l'environnement Canadien. CNRC, No 18977, Ottawa, Canada.

Merkel J.A., Hazen T.E. and Miner J.R. (1969). Iden ti fi ca tion of Gazes in a Confinement Swine Building Atmosphere. Trans. Am. Soc. Agric. Eng. 12: 310-314.

O'Neill P.H. and Stewart I.W. (1985). State of the Art Report. The Control of Odour Nuisance from Inten sive Live stock Building. National Institute of Agricultural Engineering, West Park, Silsoe, Bedford, UK.

Pain B.F. and Misilbrook T.H. (1990). Relationships Between Odor and Ammonia
Emission During and Following the Appli ca tion of Slurries to Land, Odorand Ammonia Emissions Livestock Farming. Elsevier Applied Science, London, UK.

Schaefer J. (1977). Sampling, Characterization and Analysis of Malodours. Agric. Environ. 3: 121-127.

Standard Methods for the Examination of Water and Wastewater (1995). 19 th edn, American Public Health Association/ AWWA/Water Environment Federation, Wash ington DC, USA.

Tinh V.Q., Leblanc R., Janssens J.M. and Ruel M. (1971). Peat Moss- A Natural Adsorbing Agent for the Treatment of Polluted Water. Can. Min. Metall. Bull., Vol. 64, pp 99-104.

VDI 3882 Olfactometry (1992). Determination of Odor Intensity. Varein Deutscher Ingenieure.

Yasuhara A., Fuwa K. and Jimbu M. (1983). Isolation and Anal ysis of Odorous Compounds in Swine Manure. J. of Chromat, 1281: 225-236. 
G. Buelna, N. Turgeon and R. Dubé

\section{Author's biographies}

Gerardo Buelna. Doctor-Engineer, Senior technical expert - Treatment and Bioconversion at the Industrial Research Center of Quebec (CRIQ) and associate professor at Laval University (Quebec, Canada), is an internationally renowned expert in the treat ment of gaseous and liquid effluents through biolog ical filtra tion. He is the author of over 70 publi ca tions in numerous national and inter na tional maga zines as well as two patents. Dr. Buelna obtained the SNC 1991 award of excel lence awarded by Sciences et Tech niques de l'eau (AQTE) maga zine and was the recipient of the 1998 Michel-Jurdant award, dedicated to environmental sciences and awarded by the Association Canadienne-Française pour l'Avancement des Sciences (ACFAS).

Nicolas Turgeon. Holds a Bach e lor's degree in civil engi neering from Université Laval (Québec City) and a Master's in the envi ron ment also from Laval. He has been working as a research and devel op ment agent and project manager in the Envi ron ment Divi sion of CRIQ since 1997. He is involved in devel oping Biotechniques for Air pollu tion Control.

Rino Dubé. Holds a Bach e lor's degree in civil engi neering from Université Laval (Québec City) and a Master's in the envi ron ment also from Laval. He has been working as a research and devel op ment agent in the Envi ron ment Divi sion of CRIQ since 1995. He is involved in devel oping and fine tuning the organic bed biofiltration process, in particular for treating indus trial and agri cul tural effluents. 